\title{
Ever since Darwin?
}

\author{
¿Siempre desde Darwin? \\ PATRICIO A. CAMUS \\ Departamento de Ecología Costera, Facultad de Ciencias, Universidad Católica de la Santísima Concepción, \\ Casilla 297, Concepción, Chile \\ e-mail: pcamus@ucsc.cl
}

\begin{abstract}
Throughout the whole year 2009, the global biological community has celebrated the legacy of Charles Darwin, commemorating the anniversaries of his birth and the publication of "The origin", one of the most influential books of modern history. In this context, the Revista Chilena de Historia Natural inaugurates its new "Special Features" section with four independent essays dealing with the past, present and future of Darwin's ideas. This initial presentation focuses on some loose ends of this Darwinfest, particularly on some forgotten anniversaries directly or indirectly related with Darwin's, and summarizes the contributions of the three essays following this introduction in the present issue.
\end{abstract}

Key words: Darwinism, Lamarck, natural selection, Wallace.

\section{RESUMEN}

Durante todo el año 2009, la comunidad biológica global ha celebrado el legado de Charles Darwin, conmemorando los aniversarios de su nacimiento y de la publicación del "Origen", uno de los libros más influyentes en la historia moderna. En este contexto, la Revista Chilena de Historia Natural inaugura su nueva sección de "Temas Especiales" con cuatro ensayos independientes que tratan sobre el pasado, presente y futuro de las ideas de Darwin. Esta presentación inicial se enfoca en algunos cabos sueltos de la celebración darwiniana, particularmente en algunos aniversarios olvidados relacionados directa o indirectamente con los de Darwin, y resume las contribuciones de los tres ensayos que siguen a esta introducción en este número de la revista.

Palabras clave: darwinismo, Lamarck, selección natural, Wallace.

\section{PRESENTATION}

Throughout the whole year 2009, the global biological community has celebrated the legacy of Charles Robert Darwin, commemorating the $200^{\text {th }}$ anniversary of his birth (February 12, 1809 ), and the $150^{\text {th }}$ anniversary of the publication of his major work "On the origin of species by means of natural selection, or the preservation of favoured races in the struggle for life" (November 24, 1859), one of the most important and influential books of modern history.

The Revista Chilena de Historia Natural (RCHN) is pleased to contribute to the Darwinfest, a most propitious occasion to inaugurate its new "Special Features" section, aimed at publishing thematic papers on relevant or novel topics in natural history, ecology and evolution. At the time of Darwin's death (April 19, 1882), organic evolution and natural selection were still not widely acknowledged, but fifteen years later Professor Carlos E. Porter founded RCHN (see Jaksic 1997), a journal devoted to strengthening naturalist research in South America following the tradition of $19^{\text {th }}$ century scholars. Therefore, it was proper to schedule this first Special Feature for our December issue, coincident with the $67^{\text {th }}$ anniversary of Carlos Porter's death (December 13, 1942; Etcheverry 1988), and right after the November anniversary of 
"The origin" and the $112^{\text {th }}$ anniversary of the first published issue of RCHN in October 1897.

However, as the multiple celebrations are coming to an end, not much remains to be said about Darwin's contribution to science and society, and it would be time to refocus on the present and the future. For instance, we should remember that evolution education in Chile (at the high school level) is just recovering from its "dark age" during the military government, which resulted in the virtual elimination of evolutionary topics from textbooks at the mid 80s (Medel 2008). This situation has changed drastically and positively in the last two decades (Camus 2009), but there is still much to do to ensure that new generations of students and teachers acquire a proper perspective on the facts and theories of evolution. So far, Chilean education is free of creationist influences, but distorted arguments pervade the media (e.g., internet), and the public (students and teachers included) cannot escape this sideeffect of globalization (Camus 2009). The misuse and abuse of evolution-related terms (e.g., "Darwinism") is widespread, and they are now popular in flawed rhetoric and "straw man" fallacies aiming to portray evolutionary theory as a very narrow ideology (an "ism") linked with a single person 150 years ago (see Scott \& Branch 2009). When using such terms in education and public domains, therefore, scientists and teachers should be very careful as to avoid far-reaching consequences.

But what happens within Biology? Darwin's ideas, so familiar and widespread, lie at the heart of modern evolutionary theory. However, after nearly 70 years of the modern synthesis, we should ask to what extent Biology continues to be Darwinian (see Folguera \& Bozinovic 2009 in this issue), and it is interesting to wonder if Dobzhansky, faced with contemporary theories, would still agree with his famous aphorism. But the point is that after natural selection emerged, it became the core of the "modern synthesis", and still reigns in several fields of Biology. Why and how this happened are not simple questions, considering that few ideas in Biology have been so often accused of being flawed or announced to vanish, and even fewer continue to survive and preserve their fundamental grounds. The success of natural selection is often attributed to its remarkable simplicity, which led Thomas
Huxley (after reading "The origin") to exclaim "How stupid of me not to have though of that!" (Worster 1994), and to its apparent ubiquity, reinforced by the independent discovery of Alfred Wallace (see below) suggesting that it was a common and widespread mechanistic fact, ready to be detected by a watchful and properly informed eye.

Nonetheless, an in depth appreciation of the rise and success of natural selection puts the question into a more complex and often nonbiological scenario (e.g., Salthe 2006, 2008; see also Marquet 2009 in this issue), involving logical, cultural, economical, political, and thermodynamical arguments, among others. Acknowledging such scenario by no means discredits Darwin and his role in the consolidation of evolutionary thinking, but it does circumscribe the biological relevance of natural selection, and also warns us against conflating Darwin's theory with evolutionary theory or evolution itself. In addition, such a conflation exposes a weak flank for creationists, and this is one of several reasons for which modern evolutionary biology should not be referred to as "Darwinism" or synonymized with it. For instance (following Scott \& Branch 2009), this term bears a restrictive view of evolutionary phenomena and the vast scope of current evolutionary research, and an unfair touch to all scientists who have contributed "to the scientific edifice to which Darwin provide the cornerstone". It is for this latter reason that the following section deals with two anniversaries directly or indirectly related with Darwin's, which should not be forgotten this year.

\section{SOME FORGOTTEN ANNIVERSARIES}

It is clear that the life and work of Darwin have, for good or bad, dominated our view of the development of evolutionary theory, and his figure has been prominent enough as to eclipse many of his predecessors and contemporaries, some of them mistreated by history. Therefore, it seems fair to mention at least a couple of anniversaries much less celebrated than Darwin's, although deserving a better remembrance as they involve exceptional scientists whose ideas made them somewhat infamous in life. 
The "Ternate essay" and the "joint essay", or the $151^{\text {st }}$ birthday of natural selection

Sometimes an unpublished manuscript precipitates history, such as that by Alfred Russell Wallace (1823-1913), inextricably linked with the rise of Darwin to his central place in Biology. Last year happened to be the $150^{\text {th }}$ anniversary of the so-called Ternate essay ("On the tendency of varieties to depart indefinitely from the original type"), written by Wallace in February 1858 at the city of Ternate, eastern Indonesia, and then sent to Darwin for his perusal. The manuscript contained a clear, concise and elegant description of natural selection, construed in virtually the same terms Darwin had conceived after decades of work, which made a strong impression on him, and a strong urge to do something with his still unpublished material.

Notwithstanding, the Ternate essay is not precisely remembered for its indisputable theoretical significance, but rather for triggering the process that led (by mediation of Charles Lyell and Joseph Hooker) to two crucial events in the history of Biology: the presentation of the famous "joint essay" of Darwin and Wallace (both of them absent) before the Linnean Society in July 1858, and the publication of "The origin" one year later (see Gardiner et al. 2008 on these and related themes). These events established the priority of Darwin as founder of the new theory, and relegated Wallace to play a largely secondary role. Worth to note, Darwin was a respected member of the Linnean Society since 1854, but Wallace's membership was not proposed until 1871 (Gardiner 1995). Nonetheless, "it should in all fairness to Darwin be noted that Wallace took full advantage" of the recognition implied in the joint essay, which represented "an opportunity he might not otherwise have received" (Smith 2009). But, regrettably, popular culture has nearly epitomized Wallace as merely the "catalyst" of Darwin's masterpiece. Thus, an interesting question is to what extent things had been different if the Ternate essay had got published first (reminding that Wallace was not aiming to do so when he sent it to Darwin).

Prior to the joint essay, a key episode occurred that could have resulted in a drastic turn of events, and in one of the noblest gestures in academic history. After reading the Ternate essay, Darwin did two things: he readily communicated Hooker his determination to abandon all claim to priority for the new theory and to postpone his own publication in favor of Wallace's, and in parallel wrote a letter to Wallace indicating that he would not publish before him (Gardiner 1995). However, Hooker and Lyell convinced Darwin otherwise; the letter to Wallace was not posted, and he apparently was never aware of Darwin's original intention. Knowing what occurred later, it is tempting to suggest that Wallace made a wrong career move, providing a notable example of the maxim "publish or perish". In addition, Wallace soon became committed to some unconventional ideas at that time (e.g., socialism, spiritualism, women vote, etc.), not exactly helpful for his career (Gardiner et al. 2008). However, owing to Darwin's reputation and extensive prior work, it seems little probable that an eventual acceptance of Wallace's publication priority had made a major difference in the final outcome. Even so, "The origin" had likely remained a landmark work anyway and, just like it actually happened, "Darwin would overshadow Wallace from that point on" (Smith 2009).

The fact is that Wallace, a person "decent to a fault" and "not particularly interested in receiving honoraria" (see Smith 2009), never got a permanent position and found himself in a near-poverty situation, so that Darwin, helped by Thomas Huxley, had to convince the government for granting Wallace a modest annual pension (actually, slightly "smaller than the annual bill for meat at Darwin's house"; Gardiner et al. 2008: p. 116). Nevertheless, it is also a fact that Wallace never complained, always refused any priority over his admired colleague Darwin, and later even entitled one of his more important books as "Darwinism" (Gardiner et al. 2008, Smith 2009). Having long survived Darwin, Wallace became widely respected and received numerous honors for his multiple accomplishments. However, such recognition still tastes like a minor consolation prize for the co-discoverer of natural selection and father of zoogeography.

The first biologist: 253 years of his birth, and 200 years of his major work

Some naturalists did not apparently succeed in leaving a universally celebrated legacy, but they 
did left visible marks in history which, at the very least, allowed others to succeed. Such is the case of Jean-Baptiste Lamarck (1774-1829), the man who first developed a complete and coherent theory of evolution, rejecting the prevailing view on the immutable character of species (Packard 1901, Kampourakis \& Zogza 2006, Por 2006). It is often said that Lamarck coined or first used the term biology, but the term existed long before him and it was employed in different senses, early referring to biography or biographer, and later to zoology or (as used by Michael Hanov) to a broad discipline divided into zoology and "phytology" (McLaughlin 2002). However, Lamarck went further: in 1802, looking for a proper definition of his own interdisciplinary career and his evolutionary perspective, he introduced (or reinvented) the term Biology in its modern sense, to describe the study of living beings and natural phenomena with an historical and integrative dimension (e.g., see Gould 1999a, 1999b, Por 2006). Thus, we should likely refer to Lamarck as the first biologist.

Therefore, it is pertinent to remember this year the $180^{\text {th }}$ anniversary of Lamarck's death, but most especially the $200^{\text {th }}$ anniversary of the publication of his "Philosophie Zoologique" in 1809, his major work containing the basic ingredients of modern evolutionary theories. As shown in Gould's (1999a, 1999b) enlightening essays, Lamarck was "one of the finest intellects in the history of Biology", and a chronological examination of his work reveals a genuine commitment to an in depth understanding of the true meaning of evolution, which led him to acknowledge important failures in his early views, such as the single linear progression of living forms, which he abandoned in favor of branching as the fundamental pattern of evolution.

As a natural philosopher, Lamarck (formerly a distinguished botanist) contributed to a wide spectrum of disciplines but most remarkably to zoology, where his increasing understanding of organic complexity gave the final form to his view of evolution (see Gould 1999b). Lamarck's theory did not consider variation and selection, but did include general or precursory notions (not necessarily precise or correct in modern sense) of now quite familiar ideas, such as evolutionary branching leading to diversification (an early though not the first conception of the "tree of life", later refined by Darwin), descent with modification through inheritance, and adaptation to changing environments. Nowadays, nonetheless, some central aspects of Lamarck's work (inheritance of acquired characters, transformational pattern of evolution, directed changes; Kronfeldner 2007), are no longer automatically ridiculed and stigmatized. Modern biology is increasingly appreciating the importance of evolutionary processes reminiscent of Lamarckian mechanisms, from genetic assimilation and epigenetic inheritance to horizontal gene transfer, beside those already envisaged such as maternal imprinting and cytoplasmatic inheritance (see Por 2006). In addition, recent views indicate that cultural changes arising from problem solving are directed, and thus "culture is driven by a Lamarckian generation of novelty at the cognitive level and, as a consequence, at the cultural level" (Kronfeldner 2007).

Again, popular culture has preserved a largely trivialized and distorted image of Lamarck, partly derived simply from translation errors and misinterpretation of his writings, or an inflated exaggeration of some minor aspects, such as the endlessly and mistakenly cited case of the giraffe, commented in only two sentences of the Philosophie Zoologique (see Kampourakis \& Zogza 2006). However, the "fall" of Lamarck started with the unfortunate writings of his junior colleague Georges Cuvier, who was favored by Lamarck in the beginning of his career (Packard 1901). Cuvier, opposed to evolution, "used his established role as writer of eloges ... to compose a cruel masterpiece", "a document that fixed and destroyed Lamarck's reputation" during his lifetime (Gould 1999a). In a sad epilogue, the father of evolutionary theories "died alone, blind and impoverished" (Gould 1999a). After that, most naturalists adopted a negative attitude toward Lamarck's ideas on evolution, including Wallace who rejected them from the beginning (Gardiner et al. 2008), and Darwin who maintained a curiously ambivalent posture (see below). But not even Darwin's bulldog Thomas Huxley, who rejected progressive evolution, would dismiss the scientific importance of Lamarck. The year of Darwin's death, Huxley wrote about "Darwin's position in the history of science", concluding that only Lamarck and Buffon "would run him 
hard in both genius and fertility", as they "were giants" "in breadth of view and in extent of knowledge" (see Packard 1901).

Thus, not all has been said about Lamarck's place in history, and there is still a final interesting remark. The influences that first led Darwin to adopt a transmutationist view at some early point of his career remain intriguing, and Lamarckian ideas apparently played a more important role than admitted, which would hardly be a surprise because "no one, after all, works in a vacuum" (see Eldredge 2009).

\section{ABOUT THIS SPECIAL FEATURE}

After so numerous commemorations worldwide, this Special Feature does not aim to repeat well-known arguments on Darwin or "The origin", but rather call the attention on some loose ends and complementary aspects, as those dealt with in this introduction. Thus, the three independent essays following this presentation in the present issue of RCHN focus on the past, present and future of Darwin's ideas, although in different contexts.

Firstly, Castilla (2009) explores the significance of Darwin's famous monographs on barnacles for the development oh his theory of evolution. The investigation conducted for these monographs, confidently started by Darwin, took in fact eight years to complete, and apparently forced him to set aside his unfinished writings on evolution (one of his letters is quite informative about his feelings, referring to his "tedious work" on the second volume of the Cirripedia, "... of which creatures I am wonderfully tired: I hate a Barnacle as no man ever did before ..."; Darwin 1852). Then, did barnacles waste Darwin's time, preventing an earlier publication of "The origin"? Insightfully, Castilla suggests that, on the contrary, the work on Cirripedia "paved the way and provided Darwin with the conviction, and confidence, he needed for the final publication of his theory on the origin and mutability of species". Moreover, Castilla considers that barnacles provided Darwin "one of the richest sources of biological material ... to initiate an exhaustive study, and test some of his central hypotheses concerning evolution". In fact, after publishing his monographs, Darwin "devoted his whole time to arranging his huge pile of notes, to observing, and to experimenting in relation to the transmutation of species" (Gardiner 1995). So, Castilla may really have a point.

In the second essay, Folguera \& Bozinovic (2009) evaluate how Darwinian is contemporary Biology, by examining some of the main contributions of the original Darwinism to the sciences of living systems, including the recognition of proximate causes, common ancestry and diversification, and the role of variability and chance. According with the authors, most disciplines of modern Biology would maintain continuity with Darwin's ideas, although sometimes with a biased perspective (e.g. panselectionism). In fact, Folguera \& Bozinovic argue that a wide incorporation of Darwinian ideas, not just as accepted theories but rather as research programs, should be conceived as an important challenge to develop a coherent integrative Biology. Such a radical proposition may challenge some readers too, but in some fields there is indeed a renewed interest in Darwinian processes (e.g., natural selection as inferred from the fossil record; Bell et al. 2006, Hendry 2008). In that regard, Folguera \& Bozinovic comment on the predominance of a mode-centered approach in some fields of Biology (mainly in applied disciplines), which disregards the importance of variability in natural phenomena and tends to preserve some little cherished aspects of Lamackism and essentialism. At least in some areas, thus, Biology would still need a greater "Darwinization" to become more realistic (but see below); it suffices to say that this very idea is a huge tribute to Darwin.

Finally, Marquet (2009) discusses the possibility to expand evolutionary theory in the Darwinian tradition by incorporating an interaction between the processes of natural selection, self-organization and niche construction. For such purpose, it is necessary to acknowledge that natural selection alone cannot explain the evolution of complexity in living systems (e.g., see Salthe 2008) and it plays just a partial role in the processes driving adaptive change. A central argument in Marquet's essay is that "the environment carries the footprint of its past and present inhabitants", and "organisms do have an active role in shaping and constructing the environment they inhabit, and in doing so modify the biotic and abiotic sources 
of natural selection upon them and on other organisms". Such circularity, as depicted by the theory of niche construction, complements the role of natural selection (a strictly onedirectional process) as much as does selforganization, or the emergence of order and structures in open non-equilibrium system maintained by fluxes of energy and materials. Consequently, Marquet states that selforganization may provide a framework to understand the emergence of natural selection, while niche construction would be the fundamental connection between both. If evolution is based on networks of causation and feedback, then we may expect a significant reorientation of evolutionary theory (Laland et al. 2004), and consequently of Biology.

To conclude this introduction, we may say that Biology born Lamarckian and grew Darwinian, but at some point along its way it became something else. Thus, the science of Biology must yet resolve its present status and future directions, but meanwhile, we should concur with Gould's (1976) suspicion on that "we'll have Charles Darwin to kick around for some time".

\section{LITERATURE CITED}

BELL MA, MP TRAVIS \& DM BLOUW (2006) Inferring natural selection in a fossil threespine stickleback. Paleobiology 32: 562-577.

CAMUS PA (2009) Evolución y educación científica en Chile: problemas funcionales y conflictos entre enseñar y aprender: 19-31. In: D’Elía G (ed) Una celebración de los aniversarios darwinianos de 2009. Gayana 73 (suplemento). 88 pp.

CASTILLA JC (2009) Darwin the taxonomist: Barnacles and shell burrowing barnacles. Revista Chilena de Historia Natural 82: 477-483.

DARWIN C (1852) Letter no. 1489, Darwin Correspondence Project Database. URL: http:// www.darwinproject.ac.uk/entry-1489/ (accessed December 12, 2009)

ELDREDGE N (2009) Experimenting with transmutation: Darwin, the Beagle, and evolution. Evolution, Education and Outreach 2: 35-54.

ETCHEVERRY M (1988) Datos biográficos sobre don Carlos Emilio Porter Mossó (1867-1942). Revista Chilena de Historia Natural 61: 127-128.

FOLGUERA \& F BOZINOVIC (2009) A los 150 Años desde "El origen de las especies": ¿Es darwinista la biología contemporánea? Revista Chilena de Historia Natural 82: 485-491.
GARDINER B (1995) The joint essay of Darwin and Wallace. The Linnean 11: 13-24.

GARDINER B, R MILNER \& M MORRIS (eds) (2008) Survival of the fittest. A special issue of The Linnean celebrating the $150^{\text {th }}$ anniversary of the Darwin-Wallace theory of evolution. The Linnean Special Issue 9, Willey-Blackwell, Oxford. $117 \mathrm{pp}$ URL: http://www.linnean.org/fileadmin/images/ Linnean/Special_Issue_9_-_Celebrating_the_150th_ anniversary_of_the_Darwin-Wallace_theory_ of_evolution.pdf (accessed November 23, 2009)

GOULD SJ (1976) Darwin's untimely burial. Natural History 85 (October): 24-30.

GOULD SJ (1999a) Branching through a wormhole. Natural History 108 (March): 24-27, 84-89.

GOULD SJ (1999b) A division of worms: Jean Baptiste Lamarck's contributions to evolutionary theory. Natural History 108 (February): 18-22, 76-81.

HENDRY AP (2008) Evolutionary biology: Darwin in the fossils. Nature 451: 779-780.

JAKSIC FM (1997) The first hundred years of the Revista Chilena de Historia Natural. Revista Chilena de Historia Natural 70: 5-8.

KAMPOURAKIS K \& V ZOGZA (2006) Students' preconceptions about evolution: How accurate is the characterization as "Lamarckian" when considering the history of evolutionary thought? Science and Education 16: 393-422.

KRONFELDNER ME (2007) Is cultural evolution Lamarckian? Biology and Philosophy 22: 493-512.

LALAND KN, J ODLING-SMEE \& MW FELDMAN (2004) Causing a commotion. Nature 429: 609.

McLAUGHLIN P (2002) Naming biology. Journal of the History of Biology 35: 1-4.

MARQUET PA (2009) Beyond Darwin: On the role of niche construction and self-organization in evolution. Revista Chilena de Historia Natural 82: 493-496

MEDEL RG (2008) The evolution of evolutionary thinking in Chile. Evolution, Education and Outreach 1: 318322.

PACKARD AS (1901) Lamarck, the founder of evolution; his life and work. Longmans, Green, and Co., New York. $451 \mathrm{pp}$

POR FD (2006) The actuality of Lamarck: Towards the bicentenary of his Philosophie Zoologique. Integrative Zoology 1: 48-52.

SALTHE SN (2006) Analysis and critique of the concept of natural selection (and of the neoDarwinian theory of evolution) in respect (Part 1) to its suitability as part of modernism's origination myth, as well as (Part 2) of its ability to explain organic evolution. URL: http://www.nbi.dk/ natphil/salthe/ Critique_of_Natural_Select_.pdf (accessed December 2, 2009)

SALTHE SN (2008) Natural selection in relation to complexity. Artificial Life 14: 363-374.

SCOTT \& BRANCH (2009) Don't call it "Darwinism". Evolution, Education and Outreach 2: 90-94.

SMITH CH (2009) Alfred Russel Wallace: A capsule biography. URL: http://www.wku.edu/ smithch/ wallace/BIOG.htm (accessed November 24, 2009)

WORSTER D (1994) Nature's economy. A history of ecological ideas. Second edition. Cambridge University Press, New York. 473 pp. 